\title{
Relationship Between Bilirubin UDP-Glucuronosyl Transferase 1A1 Gene and Neonatal Hyperbilirubinemia
}

\author{
CHING-SHAN HUANG, PI-FENG CHANG, MAY-JEN HUANG, EN-SUNG CHEN, \\ KUN-LONG HUNG, AND KUO-INN TSOU \\ Departments of Laboratory Medicine [C.S.H., M.J.H., E.S.C.] and Pediatrics [P.F.C., K.L.H.], Cathay \\ General Hospital, No.280, Sec 4, Jen Ai Road, Taipei 106, Taiwan, and School of Medicine [K.I.T.], \\ Fu-Jen Catholic University, No.511, Jong Jeng Road, Shin Jaung 242, Taiwan
}

\begin{abstract}
The variation rate within the coding region of UDPglucuronosyl transferase 1A1 (UGT1A1) gene in Taiwan Chinese was found to be $29.3 \%$. This study sought to determine whether that high variation rate of UGT1A1 gene is a risk factor for neonatal hyperbilirubinemia. The study subjects consisted of 123 newborn infants suffering from unconjugated hyperbilirubinemia who had no known risk factors for hyperbilirubinemia and 218 healthy control neonates. The promoter area, exons 1 to 4 , coding region of exon 5, and the flanking intronic regions in $\overline{U G} \bar{T} \overline{1 A 1}$ gene were determined by the PCR in all subjects. Wild UGT1A1 gene, variation in the promoter, variation at nucleotide 211, variation at nucleotide 1091, and compound heterozygous variation of UGT1A1 gene were found. The percentage of neonates with wild UGT1A1 gene and the percentage of neonates with variation at nucleotide 211 were significantly different between the study subjects and controls. The percentages with bilirubin
\end{abstract}

\footnotetext{
the study subjects and controls. The percentages with bilirubin
}

\section{Unauthor}

UDP-glucuronosyl transferase 1A1 (UGT1A1) is the key enzyme for bilirubin conjugation. Defects in this enzyme can cause a nonhemolytic unconjugated hyperbilirubinemia such as Crigler-Najjar syndrome type 1 (CN 1), type $2(\mathrm{CN} 2)$ and Gilbert's syndrome. Because UGT1A1 is too labile to be measured by classic biochemical methods, nonhemolytic unconjugated hyperbilirubinemia is ideally studied at the genetic level (1). The cDNA of human UGT1A1 gene was found to be located at chromosome 2q37 and was cloned in 1991 (1). This led to the detection of genetic defects in patients with CN 1 (2), CN 2 (3), and Gilbert's syndrome (4). CN 1 and Gilbert's syndrome have been shown to be mainly associated with mutations in exons 2 to 5 and promoter area, respectively (5).

February 15, 2002; May 23, 2002.

Correspondence: Professor Ching-Shan Huang, Department of Laboratory Medicine, Cathay General Hospital, No.280, Sec 4, Jen Ai Road, Taipei 106, Taiwan; e-mail: pcsh@ms1.cgh.org.tw

Supported by a grant from the National Science Council, Taiwan; contract number: NSC 89-2320-B-281-001

DOI: 10.1023/01.PDR.0000028058.44773.24
CN 2 and Gilbert's syndrome may be inherited as a recessive trait or as a dominant trait $(4,6,7)$.

The peak serum levels of unconjugated bilirubin in full-term Asian (Japanese, Korean, or Chinese) and American Indian neonates are double those in Caucasian and black populations (8). The incidence of kernicterus is also higher among Asian newborn infants (9). These findings suggest that genetic factors are involved in the development of neonatal hyperbilirubinemia. Recently, homozygous A(TA) 7 TAA variation in promoter of UGT1A1 gene was found to be associated with neonatal hyperbilirubinemia in Sephardic Jews (10), Americans (11), Italians (12, 13), and British (14). However, in Japanese studies, the high allele-frequency of Gly71Arg in UGT1A1 gene was found to be responsible for neonatal hyperbilirubinemia without obvious cause $(15,16)$. These reports reveal that the relationship between the site of variant UGT1A1 gene and neonatal hyperbilirubinemia may differ among ethnic groups.

Very recently, we used the technique of PCR to determine the UGT1A1 gene in Taiwan Chinese adults and found that the 
occurrence of $\mathrm{A}(\mathrm{TA})_{7} \mathrm{TAA}$ allele was relatively rare $(14.3 \%$ versus $40 \%$ ) and the variation rate within the coding region was much higher $(29.3 \%$ versus $0.1 \%)$ in Taiwan Chinese compared with Caucasians (17). In addition, we found a novel compound heterozygous variation within the coding region of the UGT1Al gene that caused CN 2 in an adult patient (18). We hypothesized that the variations in the coding region of the UGT1A1 gene may be related to the development of neonatal hyperbilirubinemia. We performed this study to determine whether this association existed. To the best of our knowledge, this study is the pioneering research of UGTIAl gene in Chinese neonates.

\section{METHODS}

Study subjects and healthy controls. Neonatal hyperbilirubinemia was diagnosed if a newborn infant needed phototherapy and had a bilirubin level $\geqq 256.5 \mu \mathrm{M}(15.0 \mathrm{mg} / \mathrm{dL})$ in serum $(8,19)$ within 1 week after birth. From August 1999 through October 2000 at Cathay General Hospital, Taipei, Taiwan, 289 neonates (174 males and 115 females) suffered from neonatal hyperbilirubinemia. In addition, 25 neonates (14 males and 11 females) with hyperbilirubinemia were referred for investigation from National Taiwan University Hospital, Taipei, Taiwan. Totally 314 newborn infants were enrolled and the known risk factors for neonatal hyperbilirubinemia were investigated. Among the 314 newborn infants with neonatal hyperbilirubinemia, 191 had at least one known risk factor for the development of this disease (Table 1). The most frequent risk factor was breast milk feeding, followed by premature birth, ABO incompatibility, hypoxia/asphyxia, dehydration/ vomiting, glucose-6-phosphate dehydrogenase (G6PD) deficiency, cephalohematoma, sepsis, and low birth weight/Some subjects had multiple risk factors (two or three factors) as shown in Table 1. The remaining 123 neonates $(73$ males and 50 females) had nonhemolytic unconjugated hyperbilirubinemia without obvious risk factors for hyperbilirubinemia. They were selected as the study group and were followed for 3 weeks. A bilirubin level $\geqq 342 \mu \mathrm{M}^{-}(20.0 \mathrm{mg} / \mathrm{dL})$ was considered an indication for blood exchange (19). Persistent hyperbilirubinemia was defined as a bilirubin value over 150 $\mu \mathrm{M}(8.8 \mathrm{mg} / \mathrm{dL})$ at day 14 of life (14). Control subjects (130 males and 88 females) were selected from full-term neonates

Table 1. Risk factors for neonatal hyperbilirubinemia in 191 newborn infants

\begin{tabular}{lc}
\hline \multicolumn{1}{c}{ Risk factor } & $n$ \\
\hline Breast milk feeding & 38 \\
Premature birth & 36 \\
ABO incompatibility & 31 \\
Hypoxia/asphyxia & 25 \\
Dehydration/vomiting & 9 \\
G6PD deficiency & 8 \\
Cephalohematoma & 6 \\
Sepsis & 3 \\
Low birth weight & 1 \\
Two risk factors & $30^{*}$ \\
Three risk factors & $4 \dagger$ \\
\hline
\end{tabular}

Four subjects * and three subjects $\dagger$ were G6PD deficient. born at Cathay General Hospital who had no known risk factors for neonatal hyperbilirubinemia, had peak bilirubin values $<256.5 \mu \mathrm{M}(15.0 \mathrm{mg} / \mathrm{dL})$ and were apparent healthy during the 1st week of life. All the parents of study and control neonates gave consent to let their babies participating in this study that was approved by the research committee of Cathay General Hospital.

Analysis of the UGT1A1 gene. The blood samples for the analysis of the UGT1A1 gene were obtained from umbilical cord blood. Umbilical cord blood samples have been routinely collected for screening of G6PD deficiency in neonates at Cathay General Hospital since 1981 (19, 20). Total genomic DNA was isolated from whole blood cells using the blood DNA isolation kit (Maxim Biotech Inc, San Francisco, CA, U.S.A.). Exons 1 to 4 and coding region of exon 5 of the UGT1A1 gene, their flanking intronic regions, and the promoter area were amplified by PCR as previously described (17). The primers used for PCR are shown in Table 2. The amplification reaction mixture $(100 \mu \mathrm{L})$ contained $1 \mu \mathrm{g}$ DNA in $10 \mathrm{mM}$ Tris- $\mathrm{HCl} \mathrm{pH}=8.8,1.5 \mathrm{mM} \mathrm{MgCl} 2,50 \mathrm{mM} \mathrm{KCl}$, $0.1 \%$ Triton X-100, $200 \mu \mathrm{M}$ of each dNTP, $100 \mathrm{ng}$ of each primer, and $2 \mathrm{U}$ of Dynazyme DNA polymerase (Finnzymes OY, Espoo, Finland). The reaction was performed with a DNA thermal cycler (Perkin-Elmer Cetus, Norwalk, CT, U.S.A.) as follows: three cycles of denaturation at $94^{\circ} \mathrm{C}$ for $80 \mathrm{~s}$, annealing at $55^{\circ} \mathrm{C}$ for $60 \mathrm{~s}$ and primer extension at $72^{\circ} \mathrm{C}$ for $110 \mathrm{~s}$; seven cycles of denaturation at $94^{\circ} \mathrm{C}$ for $60 \mathrm{~s}$, annealing at $55^{\circ} \mathrm{C}$ for $60 \mathrm{~s}$, and extension at $72^{\circ} \mathrm{C}$ for $110 \mathrm{~s} ; 30$ cycles of denaturation at $94^{\circ} \mathrm{C}$ for $50 \mathrm{~s}$, annealing at $55^{\circ} \mathrm{C}$ for $50 \mathrm{~s}$, and extension at $72^{\circ} \mathrm{C}$ for $90 \mathrm{~s}$; and a final extension step at $72^{\circ} \mathrm{C}$ for 10 min. These PCR products were sequenced with an automated fluorescence sequencer (ABI Prism377, PE Applied Biosystems, Foster City, CA, U.S.A.), according to the manufacturer's instructions.

Statistical analysis. Student's $t$ test and $\chi^{2}$ test (with or without Yates' correction) were used to analyze the data as appropriate. A $p$ value less than 0.05 was defined as statistically significant. $S \mathrm{C}$

\section{biteol RESULTS}

Male/female ratio, gestation age and birth weight. Table 3 shows the comparisons of male/female ratio, gestation age, and birth weight between study and control groups. There were no significant differences observed.

UGT1A1 gene in newborn infants. As shown in Table 4, wild UGT1A1 gene, variation in promoter (A(TA) ${ }_{6} \mathrm{TAA} /$ $\mathrm{A}(\mathrm{TA})_{7} \mathrm{AA}(6 / 7)$ and $\left.\mathrm{A}(\mathrm{TA})_{7} \mathrm{TAA} / \mathrm{A}(\mathrm{TA})_{7} \mathrm{TAA}\right)$, variation at nucleotide 211 ( $\mathrm{G}$ to $\mathrm{A}$, heterozygous and homozygous), variation at nucleotide 1091, and compound heterozygous variation of UGTIA1 gene were all identified among the study and control subjects. The percentage of the neonates carrying wild UGT1A1 gene and the percentage of subjects having the variant nucleotide 211 were significantly different between the study and control neonates. The various allele frequencies of UGT1A1 gene are listed in Table 5. Significant difference in the frequency of $211 \mathrm{G}$ to $\mathrm{A}$ was found between the study subjects and the controls, while the frequencies of $\mathrm{A}(\mathrm{TA})_{7} \mathrm{TAA}, 686 \mathrm{C}$ 
Table 2. Primers used for PCR and sequencing of UGT1A1 gene

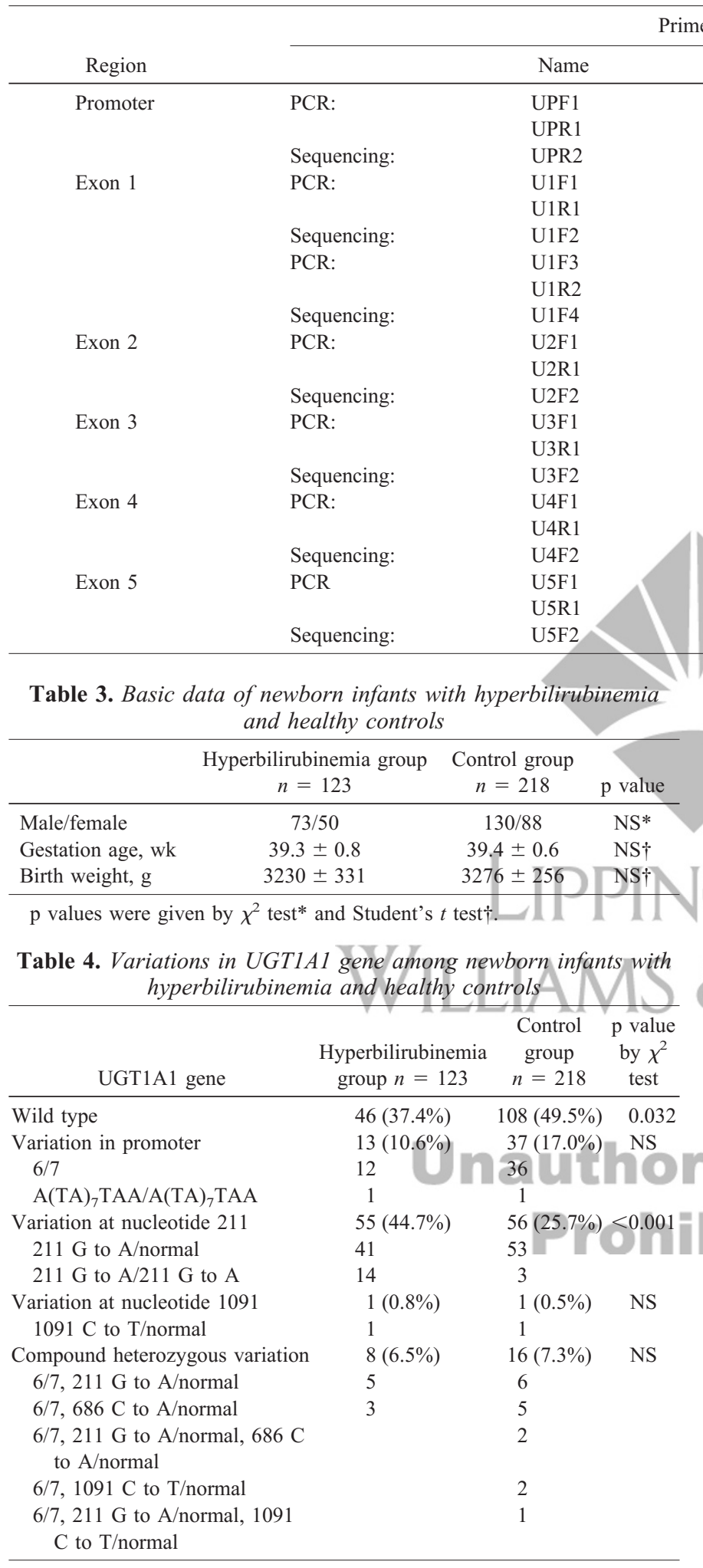

to $\mathrm{A}$ and $1091 \mathrm{C}$ to $\mathrm{T}$ were not significantly different between these two groups.

Severity of neonatal hyperbilirubinemia. To understand whether the genotypes of UGT1A1 gene influence the severity of hyperbilirubinemia, neonates of the study group carrying the variant nucleotide 211 were divided into two groups (heterozygous and homozygous variations) for further analysis. Table 6

shows the comparative severity of neonatal hyperbilirubinemia. The percentages with a bilirubin value $\geqq 342 \mu \mathrm{M}$ $(20.0 \mathrm{mg} / \mathrm{dL})$ and with persistent hyperbilirubinemia in the subjects carrying homozygous variation at nucleotide 211 were both significantly different from the neonates carrying wild type or other genotypes.

Table 5. Comparison of various allele frequencies of UGT1A1

gene between neonates with hyperbilirubinemia and healthy controls

\begin{tabular}{cccc}
\hline $\begin{array}{c}\text { Allele } \\
\text { frequency }\end{array}$ & $\begin{array}{c}\text { Newborns with } \\
\text { hyperbilirubinemia }\end{array}$ & $\begin{array}{c}\text { Healthy } \\
\text { controls }\end{array}$ & p value \\
\hline A (TA) $)_{7}$ TAA & 0.089 & 0.124 & $\mathrm{NS}^{*}$ \\
$211 \mathrm{G}$ to $\mathrm{A}$ & 0.301 & 0.156 & $<0.001^{*}$ \\
$686 \mathrm{C}$ to A & 0.012 & 0.018 & $\mathrm{NS} \dagger$ \\
$1091 \mathrm{C}$ to T & 0.004 & 0.009 & $\mathrm{NS} \dagger$
\end{tabular}

$\mathrm{p}$ values were given by $\chi^{2}$ test* and $\chi^{2}$ test with Yates' correction†.

5'GAGTATGAAATTCCAGCCAG3'

5'ATGGCACAGGGTACGTCTTC3'

5'AGATACTGTTGATCCCAGTG3'

5'GCACGTAGGAGAATGGGTTG3'

5'CAGCTTTGATGTCATGCTGA3'

5 'CGATCCAAAGTAATACATCTG ${ }^{\prime \prime}$

5'ATTCTGTAAGCAGGAACCCT

(

5'ATAGTTCTGCATCCACTTGTT3'

5'GGCTTAAGCACAGCTATTCT3'

5'CATGAATGCCATGACCAAAGT3'

5'GCCAACATATCCTACATTGC3'

rget size

495

495

497

495

560

5 GGAAATGACTAGGGAATGGT3'

5'GTAGTCTTCTTAAGCAGCCA3'

$1 \mathrm{C} 0$

A variety of etiologic factors are involved in the development of neonatal hyperbilirubinemia (21). Among these risk factors, breast milk feeding probably is the predominant as that listed in Table 1. However, in some subjects, no known risk factors are identified and further etiologic investigations are required. The UGT1A1 gene is considered as the first item requiring further investigation because UGT1A1 is the key enzyme regulating the elimination of bilirubin and the enzyme is labile and is not measured in neonates as it would involve liver biopsy. Variations in the promoter area of UGT1A1 gene result in a reduced production of $\operatorname{UGT1A1}(4,5,22)$ and variations within the coding region of this gene may result in dysfunction of UGT1A1 with abnormal structure $(2,3,5,22)$. These findings indicate that the variation of UGT1A1 gene is possibly associated with neonatal hyperbilirubinemia. Kaplan et al. (10) and Cappellini et al. (13) found that the TA repeat 
Table 6. Severity of neonatal hyperbilirubinemia in newborn infants with different UGT1A1 genotypes

\begin{tabular}{|c|c|c|c|c|}
\hline & $\begin{array}{l}\text { Homozygous } \\
211 \mathrm{G} \text { to } \mathrm{A}^{\mathrm{a}}\end{array}$ & Wild type ${ }^{\mathrm{b}}$ & $\begin{array}{c}\text { Other } \\
\text { genotypes }^{\mathrm{c}}\end{array}$ & $\begin{array}{c}\mathrm{p} \text { value by } \chi^{2} \\
\text { test* }\end{array}$ \\
\hline Bilirubin $\geqq 342 \mu \mathrm{mol} / \mathrm{L}$ & $6 / 14$ & $4 / 46$ & $8 / 63$ & $0.01^{\mathrm{a} v \mathrm{vs}}$ \\
\hline$\%$ & 42.9 & 8.7 & 12.7 & $0.019^{\text {a vs c }}$ \\
\hline$\%$ & 57.1 & 15.2 & 7.9 & $<0.001^{\text {a vs } \mathrm{c}}$ \\
\hline
\end{tabular}

* With Yates' correction.

promoter polymorphism in UGT1A1 gene increased the incidence of neonatal hyperbilirubinemia in G6PD deficiency. Iolascon et al. (12) reported that UGT1A1 promoter polymorphism accounted for increased neonatal hyperbilirubinemia of hereditary spherocytosis. The studies of Bancroft et al. (11) and Monaghan et al. (14) showed that Gilbert's syndrome (homozygous $\mathrm{A}(\mathrm{TA})_{7} \mathrm{TAA}$ variation) accelerated development of hyperbilirubinemia and contributed to prolonged hyperbilirubinemia in newborn infants. Akaba et al. (15) and Maruo et al. $(16,23)$ described that the allele frequency of the Gly71Arg variation in UGT1A1 gene was significantly higher in neonates with hyperbilirubinemia than in healthy adult controls and neonates without hyperbilirubinemia. The results of our study confirm this finding. Therefore, neonates having the variant genotype at nucleotide 211 may be at risk for the development of neonatal hyperbilirubinemia. Interestingly, the $211 \mathrm{G}$ to A variation (Gly71 Arg) has not been reported in Caucasians (4). On the other hand, the frequencies of the variant promoter in Taiwan Chinese neonates (Table 4) and adults (17) were quite low (0.089-0.143) compared with Caucasians (0.357-0.415) $(4,24-26)$. In this study, the allele frequency of A(TA ${ }_{7}$ TAA in neonates with hyperbilirubinemia who had no known risk factors was not different from that of healthy controls. Thus, the variant site associated with neonatal hyperbilirubinemia in our study subjects was at nucleotide 211 rather than in the promoter area, unlike previous findings in Caucasians (10-14). These ethnic differences may also be observed in Gilbert's syndrome and deserve further investigation.

In our previous study, we found that the bilirubin levels were correlated well to the frequencies of variant UGT1A1 gene (17). Although the variation of Gly71Arg in UGT1A1 gene was found to be associated with hyperbilirubinemia in Japanese neonates $(15,16,23)$, the comparisons of disease severity among those with different UGT1A1 genotypes were not analyzed because the sample size was small. In this study, among the hyperbilirubinemic newborn infants without known risk factors, those who carried homozygous $211 \mathrm{G}$ to A variation had worse outcome (Table 6). Moreover, the peak bilirubin level was $416 \mu \mathrm{M}(24.3 \mathrm{mg} / \mathrm{dL})$ at day 10 in a neonate carrying the homozygous 211 variant. This neonate had the most severe disease among the 123 subjects of the study group. Two units $(500 \mathrm{~mL})$ of blood exchange treatment were given to prevent kernicterus. In the in vitro expression study by Yamamoto et al. (27), the $211 \mathrm{G}$ to $\mathrm{A}$ variation in the homozygous and heterozygous state decreased the UGT1A1 enzyme activities to $32.2 \%$ and $60.2 \%$ of normal, respectively. The decreased enzyme activities are thought to cause moderate and mild delayed elimination of bilirubin (5). It is not surprising that the clinical symptoms in the neonates who carried homozygous variation at nucleotide 211 were more severe than in those who carried heterozygous 211 variant. In this study, as that we previously found in healthy Taiwan Chinese adults (17), some neonates carried compound heterozygous variations in UGT1A1 gene. The $686 \mathrm{C}$ to A variation was associated with 6/7 variant, and this correlation warrants further investigation. A few subjects carried the $1091 \mathrm{C}$ to $\mathrm{T}$ variation. Such a variation has not been reported in ethnic groups other than Taiwan Chinese.

Other genetic factors, such as G6PD deficiency, combined with the variation in UGT1A1 gene may influence the bilirubin levels in neonates $(10,13)$. Our previous research indicated that most (78.3\%) of the G6PD deficient neonates who subsequently suffered from neonatal hyperbilirubinemia carried the nucleotide $1376 \mathrm{G}$ to $\mathrm{T}$ mutation in G6PD gene (19). In this report, the data of risk factors indicated that the incidence of G6PD deficiency in the neonates with hyperbilirubinemia was $4.8 \%(15 / 314)$ (Table 1), which was approximately double that in the general population of Taiwan Chinese (19). However, the interaction of G6PD deficiency and variation in UGT1A1 gene in neonatal hyperbilirubinemia in Asian newborn infants remains to be determined. Such a study was performed by us very recently and will be published (28).

\section{CONCLUSION}

In conclusion, the $211 \mathrm{G}$ to A variation of UGT1A1 gene is a risk factor for neonatal hyperbilirubinemia. The high incidence of neonatal hyperbilirubinemia in Taiwan Chinese is partly attributable to the high frequency of this variation. The test for this variation will be useful to investigate the causes of neonatal hyperbilirubinemia without known risk factors. Pediatricians should closely follow hyperbilirubinemic newborn infants who carry homozygous $211 \mathrm{G}$ to A variation in UGT1A1 gene.

\section{REFERENCES}

1. Ritter JK, Crawford JM, Owens IS 1991 Cloning of two human liver bilirubin UDP-glucuronosyltransferase cDNAs with expression in COS-1 cells. J Biol Chem 266:1043-1047

2. Bosma PJ, Chowdhury RJ, Huang TJ, Lahiri P, Elferink RP, Van EH 1992 Mechanisms of inherited deficiencies of multiple UDP-glucuronosyltransferase isoforms in two patients with Crigler-Najjar syndrome, type I. FASEB J 6:28592863

3. Aono S, Yamada Y, Keino H, Koiwai O 1993 Identification of defect in the genes for bilirubin UDP-glucuronosyl-transferase in a patient with Crigler-Najjar syndrome type II. Biochem Biophys Res Commun 197:1239-1244

4. Bosma PJ, Chowdhury RJ, Bakker C, Gantla S, Boer AD, Oostra BA, Lindhout D, Tytgat GN, Jansen PL, Oude ER, Chowdhury RN 1995 The genetic basis of the reduced expression of bilirubin UDP-glucuronosyl transferase 1 in Gilbert's syndrome. N Engl J Med 333:1171-1175

5. Clarke DJ, Moghrabi N, Monaghan G, Cassidy A, Boxer M, Hume R, Burchell B 1997 Genetic defects of the UDP-glucuronosyltransferase-1 gene that cause 
familial non-haemolytic unconjugated hyperbilirubinaemias. Clin Chim Acta 266:63-74

6. Aono S, Adachi Y, Uyama E, Yamada Y, Keino H, Sanno T, Koiwai O, Sato H 1995 Analysis of genes for bilirubin UDP-glucuronosyl transferase in Gilbert's syndrome. Lancet 345:958-959

7. Koiwai O, Aono S, Yukihiko A, Kamisako T, Yasui Y, Nishizawa M, Sato H 1996 Crigler-Najjar syndrome type 2 is inherited both as a dominant and as a recessive trait. Hum Mol Genet 5:645-647

8. Halamek LP, Stevenson D 1997 Diseases of the fetus and infants. In: Fanaroff AA Martin RJ (eds) Neonatal-Perinatal Medicine. Mosby Co, St. Louis, pp 1345-1389

9. Maisels MJ 1994 Jaundice. In: Avery GB, Fletechen MA, MacDonald MG (eds) Neonatology, Pathophysiology and Management of the Newborn. 4th ed. New York, JB Lippincott Co, New York, pp 630-675

10. Kaplan M, Renbaum P, Levy-Lahad E, Hammerman C, Lahad A, Beutler E 1997 Gilbert's syndrome and glucose-6-phosphate dehydrogenase deficiency: a dosedependent genetic interaction crucial to neonatal hyperbilirubinemia Proc Natl Acad Sci USA 94:12128-12132

11. Bancroft JD, Kreamer B, Gourley GR 1998 Gilbert's syndrome accelerates development of neonatal jaundice. J Pediatr 132:656-660

12. Iolascon A, Faienza MF, Moretti A, Perrotta S, del Giudice EM 1998 UGT1 promoter polymorphism accounts for increased neonatal appearance of hereditary spherocytosis. Blood 91:1093

13. Cappellini MD, Martinez di Montemuns F, Sampietro M, Tarazzi D, Fiorelli G 1999 The interaction between Gilbert's syndrome and G6PD deficiency influences bilirubin levels. Br J Haematol 104:928-929

14. Monaghan G, Mclellan A, Mcgeeban A, Li VS, Mollica F, Salemi I, Din Z, Cassidy A, Hume R, Burchell B 1999 Gilbert's syndrome is a contributory factor in prolonged unconjugated hyperbilirubinemia of the newborn. J Pediatr 134:441-446

15. Akaba K, Kimura T, Sasaki A, Tanabe S, Ikegami T, Hashimoto M, Umeda H, Yoshida H, Umetsu K, Chiba H, Yuasa I, Hayasaka K 1998 Neonatal hyperbilirubinemia and mutation of the bilirubin uridine- diphosphate glucuronosyl transferase gene: a common missense mutation among Japanese, Koreans and Chinese. Biochem Mol Biol Int 46:21-26

16. Maruo Y, Nishizawa K, Sato H, Doida Y, Shimada M 1999 Association of neonatal hyperbilirubinemia with bilirubin UDP-glucuronosyltransferase polymorphism. Pediatrics 103:1224-1227
17. Huang CS, Luo GA, Huang MJ, Yu SC, Yang SS 2000 Variations of the bilirubin uridine-diphosphoglucuronosyl transferase $1 \mathrm{~A} 1$ gene in healthy Taiwanese. Pharmacogenetics 10:539-544

18. Huang CS, Luo GA, Huang MJ, Chen ES, Young TH, Chao YC 2001 A novel compound heterozygous variation of the uridine-diphosphoglucuronosyl transferase $1 \mathrm{~A} 1$ gene that causes Crigler-Najjar syndrome type II. Pharmacogenetics $11: 639-642$

19. Huang CS, Hung KL, Huang MJ, Li YC, Liu TH, Tang TK 1996 Neonatal jaundice and molecular mutations in glucose-6-phosphate dehydrogenase deficient newborn infants. Am J Hematol 51:19-25

20. Huang CS, Chen TH, Wei C, Chein TY, Jang JF 1982 The clinical application of glucose- 6- phosphate dehydrogenase quantitative test. J Formos Med Assoc 81:938944

21. Ives NK 1999 Gastroenterology Part 1. Neonatal jaundice. In: Rennie JM, Roberton NRC (eds) Textbook of neonatology, 3rd ed. Churchill-Livingston, New York, pp $715-732$

22. Sampietro M, Iolascon A 1999 Molecular pathology of Crigler-Najjar type I and II and Gilbert's syndromes. Haematologica 84:150-157

23. Maruo Y, Nishizawa K, Sato H, Sawa H, Shimada M 2000 Prolonged unconjugated hyperbilirubinemia associated with breast milk and mutations of the bilirubin uridinediphosphate glucuronosyltransferase gene. Pediatrics 106:1127

24. Monaghan G, Ryan M, Seddon R, Hume R, Burchell B 1996 Genetic variation in bilirubin UDP-glucuronosyltransferase gene promoter and Gilbert's syndrome. Lancet 347:578-581

25. Monaghan G, Foster B, Jurima-Romet M, Hume R, Burchell B, Owens IS 1997 UGT1 1 genotyping in a Canadian Inuit population. Pharmacogenetics 7:153156

26. Beutler E, Gelbart T, Demina 1998 A Racial variability in the UDP-glucuronosyl transferase (UGT1A1) promoter: a balanced polymorphism for regulation of bilirubin metabolism? Proc Natl Acad Sci USA 95:8170-8174

27. Yamamoto K, Sato H, Fujiyama Y, Doida YU, Bamba T 1998 Contribution of two missense mutations (G71R and Y486D) of the bilirubin UDP glycosyltransferase (UGT1A1) gene to phenotypes of Gilbert's syndrome and Crigler-Najjar syndrome type II. Biochim Biophys Acta 1406:267-273

28. Huang CS, Chang PF, Huang MJ, Chen ES, Chen WC 2002 Glucose-6-phosphate dehydrogenase deficiency, the UDP-glucuronosyl transferase 1A1 gene, and neonatal hyperbilirubinemia. Gastroenterology 123:127-133

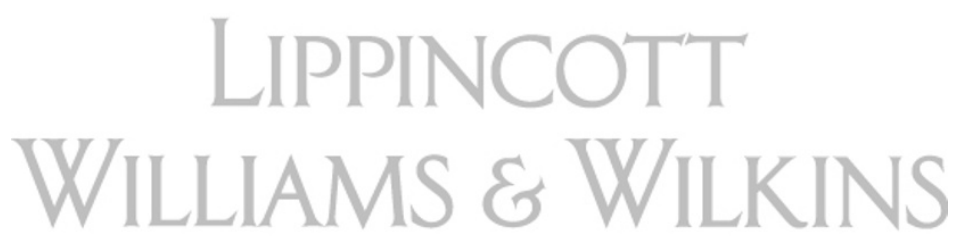

